\title{
A Survey on Plant Viruses in Natural Brassicaceae Communities Using RNA-Seq
}

\section{AUTHOR(S):}

Kamitani, Mari; Nagano, Atsushi J.; Honjo, Mie N.; Kudoh, Hiroshi

\section{CITATION:}

Kamitani, Mari ... [et al]. A Survey on Plant Viruses in Natural Brassicaceae Communities Using RNA-Seq. Microbial Ecology 2019, 78(1): 113-121

\section{ISSUE DATE:}

2019-07

URL:

http://hdl.handle.net/2433/242233

\section{RIGHT:}

This is a post-peer-review, pre-copyedit version of an article published in 'Journal of General Plant Pathology'. The final authenticated version is available online at: https://doi.org/10.1007/s00248-018-1271-4; The full-text file will be made open to the public on 24 October 2019 in accordance with publisher's 'Terms and Conditions for Self-Archiving'.; This is not the published version. Please cite only the published version.; この論文は出版社版でありません。引用の際には出 版社版をご確認ご利用ください。 
1 Title

2 A Survey on Plant Viruses in Natural Brassicaceae Communities Using RNA-Seq

3

4 The names of authors

5 Mari Kamitani ${ }^{1,2}$, Atsushi J. Nagano ${ }^{2}$, Mie N. Honjo ${ }^{1}$, Hiroshi Kudoh ${ }^{1}$

6

$7 \quad$ The affiliations and addresses of the authors

$8 \quad{ }^{1}$ Center for Ecological Research, Kyoto University, Hirano 2-509-3, Otsu 520-2113, Japan

$9 \quad{ }^{2}$ Faculty of Agriculture, Ryukoku University, Yokotani 1-5, Seta Oe-cho, Otsu 520-2914, Japan

10

11 The e-mail address and telephone numbers of the corresponding authors

$12 \quad$ Mari Kamitani

13 kamitani@ecology.kyoto-u.ac.jp

14 Hiroshi Kudoh

15 kudoh@ecology.kyoto-u.ac.jp

16 TEL: +81-77-549-8200 FAX: +81-77-549-8201

17

18 ORCID

19 Hiroshi Kudoh: 0000-0001-9777-4886

20 Mari Kamitani: 0000-0002-5803-9747

21

22

Acknowledgements

23 We would like to thank Dr. Y. Sato for his helpful comments on statistical analysis.

24 Funding information 
25 This work was supported by KAKENHI (JP26221106, 16H06171, JP16H01473), CREST (JPMJCR15O1, JPMJCR15O2), and Grant-in-Aid for JSPS Fellows (15J00628).

27

28 
Abstract

Studies on plant viruses are biased towards crop diseases and little is known about viruses in natural vegetation. We conducted extensive surveys of plant viruses in wild Brassicaceae plants occurring in three local plant communities in central Japan. We applied RNA-Seq with selective depletion of rRNA, which allowed us to detect infections of all genome-reported viruses simultaneously. Infections of Turnip mosaic virus (TuMV), Cucumber mosaic virus (CMV), Brassica yellows virus, Pelargonium zonate spot virus and Arabidopsis halleri partitivirus 1 were detected from the two perennial species, Arabidopsis halleri subsp. gemmifera and Rorippa indica. De novo assembly further detected partial sequences of a putative novel virus in Arabis fragellosa. Virus species composition and infection rate differed depending on site and plant species. Viruses were most frequently detected from the perennial clonal plant, A. halleri, in which a high clonal transmission rate of viruses across multiple years was confirmed. Phylogenetic analysis of TuMV and CMV showed that virus strains from wild Brassicaceae were included as a major clade of these viruses with other reported strains from crop plants, suggesting that viruses were shared among wild plants and crops. Our studies indicated that distribution of viruses in natural plant populations are determined by the combinations of life histories of viruses and hosts. Revealing viral distribution in the natural plant communities improves our knowledge on the ecology of plant viruses.

\section{Keywords 4 to 6 keywords}




\section{Introduction}

Plants and viruses have developed their interactions over the evolutionary time scale in natural environments. Therefore, the distribution patterns of plant viruses in natural vegetation is likely to be different from those found in agricultural fields, although studies on plant viruses have traditionally targeted to viruses that cause crop diseases. Some earlier studies investigated viruses in wild plants based on the idea that natural vegetation may have served as a reservoir for diseases [1, 2]. More recently, increasing number of studies have become investigate plant viruses in natural vegetation aiming to understand their ecology [3-5].

In the natural plant-virus interactions, infections producing severe symptoms are considered to be adaptive for neither plants nor viruses [6]. Indeed, asymptomatic infections are often observed in natural plant communities [7]. Most of them are caused by low-titer viruses, which are rarely transmitted horizontally by vectors [8]. Although many previous studies have been conducted on annual plants, viral infections in perennial plants should also be examined. Plant species with longer lifespan might have a greater influence on virus epidemiology in natural plant communities [9]. In perennial plants, high infection rates by non-seed-borne viruses are expected, because transmission through clonal propagation of host plants allows long-term persistence of viruses through clonal linage of the hosts. Although non-seed-borne viruses usually show more severe symptoms than seed-borne viruses in annual plants $[8,10]$, this may not be the case in perennial plants when the virus-host interaction lasts for multiple years.

The complexity of natural plant communities (diverse plant species inhabiting the same location) might be an important determinant of distribution and abundance of viruses. Mixed cultures, including host and non-host plants, have been reported to reduce the risk of infection in crops or cultivated plants [11, 12] as the presence of non-host plants lowers the probability of vectors carrying viruses among host plants [13]. Similarly, plant communities with high species complexity have been expected to have low rates of viral infection, because the complexity is expected to lower the frequency of host-virus encounters thereby 
reducing virus transmission rates [13].

Multiple infections by more than one virus species to the same host plants are also expected to occur in natural vegetation when interactions between viruses and their hosts last long. Such co-existence might cause competitive or facilitative interactions among viruses, which are mediated by competition for host resources or suppression of host defense mechanisms [14]. Facilitation is expected to instigate co-existence of multiple viruses while competition will prevent it $[15,16]$. Spatial aggregation of virus distributions is another common pattern that can be expected in natural vegetation. Localized transmission of a pathogen among hosts or transmission by the same vector species leads to the spatial aggregation of pathogens [17, 18]. Analysis of spatial patterns of infected plants and host-virus combinations in their natural habitats will contribute to estimation of the risk of viral transmission to the susceptible hosts inhabiting the surrounding area.

To examine viral diversity in natural plant communities, it is necessary to use a methodology that enables the comprehensive detection of existing virus species. RNA sequencing (RNA-Seq), by incorporating de novo genome/transcriptome assembly, became a powerful tool for identifying both known and unknown viral RNA and DNA from plant samples [19]. This technique allows us to survey existing viruses from natural plant communities without any prior information on their distribution. In our previous study, we found a high rate of viral infection in wild Brassicaceae, Arabidopsis halleri subsp. gemmifera (hereinafter referred to as A. halleri), in its natural habitat in central Japan [20]. Based on this, we hypothesized that Brassicaceae species coexisting with A. halleri might be potential hosts for the same viruses or they may host distinct sets of viruses.

In the present study, to reveal co-infections, differences in viral infection rates among sites, and viruses shared among different plant species, we conducted a comprehensive survey of viruses in wild Brassicaceae species occurring in three local natural plant communities in central Japan. We employed RNA-Seq method modified for comprehensive viral detection [20] and reverse transcription quantitative polymerase chain 
reaction (RT-qPCR), to detect infections. We identified virus species, their natural host range, and the spatial distribution of infected plants within each locality. Co-infections, differences in viral infections among sites, and viruses shared among Brassicaceae species within each community were also analyzed. For the representative viruses that were detected from multiple localities, we applied phylogenetic analysis to relate the properties of their genomes with geographic pattern and host rages [21, 22]. Moreover, possibility of sharing of same viruses between crops and wild plants was discussed.

\section{Materials and Methods}

\section{Plants and sampling}

Plant samples were collected from three local plant communities occurring along small valleys in hills of Osaka, Shiga, and Hyogo Prefectures in central Honshu, Japan (Table 1). The first, second and third sites were upstream of Mino-gawa River, Mino, Osaka Prefecture ( $34^{\circ} 50^{\prime} \mathrm{N}, 135^{\circ} 28^{\prime} \mathrm{E}$, alt. ca. $200 \mathrm{~m}$ ); in Gongen-dani Valley, Taga, Shiga Prefecture ( $35^{\circ} 15^{\prime} \mathrm{N}, 136^{\circ} 21^{\prime}$ E, alt. ca. $\left.320 \mathrm{~m}\right)$; and upstream of Inadogawa River, Tamba, Hyogo Prefecture ( $35^{\circ} 16^{\prime} \mathrm{N}, 134^{\circ} 57^{\prime}$ E, alt. ca. $\left.310 \mathrm{~m}\right)$. Hereinafter, these sites will be referred to as Mino-gawa, Gongen-dani, and Inado-gawa, respectively.

All Brassicaceae species in the three sites were sampled at 5-20 m intervals along the valley to provide a broad picture of the viral presence within each area. Samples were collected within the flowering season of Brassicaceae when all study plant species, both annuals and perennials, were in bloom at least in part. At Mino-gawa, 73 plants representing four Brassicaceae species were sampled on June 18, 2014 and June 11, 2016. At Gongen-dani, 125 plants representing six species were sampled on June 28, 2014 and May 13, 2016. At Inado-gawa, 91 plants representing seven species were collected on May 30, June 3, and June 16, 2014. Samples collected in 2014 were used to identify virus species infecting plants, and samples collected in 2016 were used to survey a wider area within each site, using both RNA-Seq and RT-qPCR. No samples were collected in 2016 in Inado-gawa because no viruses were detected in the initial survey. 

degradation and samples were maintained at $0{ }^{\circ} \mathrm{C}$ during the transfer, and then stored at $-20{ }^{\circ} \mathrm{C}$ in the laboratory until RNA extraction.

Total RNA extraction, RNA-Seq library preparation, and sequencing

Leaf samples were completely ground by cylinder-shaped metal beads, using the multi-beads shocker expected to display high infection rates. RNaseH (Takara Bio, Japan) to detect different types of viruses simultaneously [23]. The conventional methods with oligo-dT-beads could not be applied for the viruses without poly-A tails on the $3^{\prime}$ end of their genomes. Detailed method of RNA-Seq library preparation is described in our previous study [24]. Singleend 50 bases and index sequencing were performed in HiSeq 2000 (Illumina, CA, USA) platform. regions [20]. This procedure avoids misdetections caused by partial sequence identity. The number of reads

143 from viruses turned out to be highly distinctive between infected and non-infected plants. Therefore, we 144 calculated the number of virus reads (rpm) using the total reads derived from host genes (excluding rRNA) 
as the denominator, instead of using the total reads including virus reads [20]. Details on the methods used for mapping and calculating coverage and/or read numbers are provided in a previous publication [20].

De novo assembly

To identify infection by a novel virus, de novo assembly of unmapped reads was conducted. Reads

150 that were not mapped to the reference sequences (transcriptome sequences of A. halleri as representatives

151 of Brassicaceae host sequences and genome sequences of known viruses) were treated as unmapped reads.

152 The unmapped reads of all RNA-Seq samples were pooled within each site $(28,489,176$ reads for Minogawa, 81,378,310 reads for Gongen-dani, and 14,339,016 reads for Inado-gawa) and assembled by Trinity v2.0 [25]. Contigs with at least 200 nucleotides (nt) were annotated using a Blastn homology search (NCBI) to identify virus-like sequences. Deduced amino acid (AA) sequences of these contigs were obtained using EMBOSS software provided by European Molecular Biology Laboratory [26]. A homology search of amino acid sequences was conducted using an NCBI Blastp homology search. Sequences that were annotated to any reported virus sequences with moderate similarity (50\%-90\% similarity) were treated as candidate sequences of a novel virus. If a putative novel virus is present, multiple reads derived from its genome should be found among unmapped reads. To reconstruct the putative novel virus, remapping of the RNA-Seq data on the references with the candidate contigs were conducted using RSEM v1.2.15.

To validate viral infections detected by RNA-Seq and to determine the extent of infection (Table 1), 200 ng of RNA from each sample was reverse transcribed (High-Capacity cDNA Reverse Transcription Kit, Life Technologies, CA, USA) with random primers. The RT reaction volume was $20 \mu \mathrm{L}$ and the reaction profile was $25^{\circ} \mathrm{C}$ for $10 \mathrm{~min}, 37^{\circ} \mathrm{C}$ for $120 \mathrm{~min}$, and $85^{\circ} \mathrm{C}$ for $5 \mathrm{~min}$. The qPCR that followed was 
Technologies), according to the manufacturer's instructions. Specific primers for each virus and an internal control gene were designed here or constructed based on the previous studies (see Table S1) and used in RT-qPCR reactions (10 $\mu \mathrm{M}$ each). Purified fragments of Turnip mosaic virus (TuMV), Cucumber mosaic virus (CMV), and Brassica yellows virus (BrYV) with known molarity were used to estimate molarity and set the cycle threshold (CT) value of each infection.

All statistical analyses were conducted in R v3.2.2. Differences in virus species composition among sites and plant species were examined using multivariate analysis of variance with 9,999 permutations (perMANOVA). The vegan package in $\mathrm{R}$ and its adonis function using Bray-Curtis similarity were used [27] by setting virus species composition (the presence/absence of five viruses) within plants as the response variable and site, host species, and the interaction between site and host species as the explanatory variables. frequent than expected by chance. Tests were conducted for each site using the fisher.test function implemented in $\mathrm{R}$, with a two-tailed test.

Phylogenetic analysis of viruses

Phylogenetic analysis of TuMV was conducted using first protein (P1) and coat protein (CP) nucleotide sequences, because TuMV strains can be divided into four major lineages based on the sequences [22]. Well-sequenced (>80\% of full genome determined) strains, including six TuMV from Mino-gawa, six TuMV strains from our previous study [20], and reported TuMV strains (46 sequences) [22], were used. Japanese yam mosaic virus was added as an out-group (NCBI accession no. AB016500 and NC_000947). 
frame (ORF), in addition to, 92 and 123 bp of $5^{\prime}$ and $3^{\prime}$ untranslated region, respectively [28, 29]. Four strains of CMV from Mino-gawa, four strains from our previous study [20], and reported CMV strains (46 sequences) were used, setting Peanut stunt virus as out-group. Representative sequences of TuMV and CMV obtained in the present study were deposited in GenBank (Accession Nos. LC368037-LC368038 and LC368039, respectively). Alignments were performed in MAFFT v7.273 with default settings (http://mafft.cbrc.jp/alignment/software/). Phylogenetic analysis was conducted in MEGA v7 [30] using the maximum-likelihood method based on the Tamura-Nei model for TuMV and the General Time Reversible model for CMV, both chosen based on the Akaike information criterion. There were 616 positions for TuMV and 799 positions for CMV in the final datasets. Branch support was estimated by 1,000 bootstrap replications. determine whether viruses are transmitted through clonal propagation to interpret the results of the present study and of the previous one. Arabidopsis halleri propagates clonally by producing aerial daughter rosettes from the apical and lateral meristems of flowering stems (Fig. S1), which later become established in the ground after flowering stems fall down. To examine the transmission rate of each virus through the clonal propagation of A. halleri, 56 pairs of leaves from the mother and its aerial daughter rosettes were collected on June 2 in 2015, at the Omoide-gawa site, Hyogo Prefecture, Japan (Table 2). To obtain samples in which infecting virus species were already determined, we collected leaves for this experiment from a natural population of A. halleri, in which TuMV, CMV, BrYV, and AhPV1 were previously detected [20]. Daughter rosettes derived from the shoot apical meristems were used because they were most distant along the 
Results

Detection of viruses

To determine which viruses were present in the three plant communities, the maximum read number and maximum coverage for each virus across samples within the site, were examined for each virus (Fig.

1). To screen for viruses in Brassicaceae plant communities, data from all plants within each site was pooled. Five, two, and zero viruses were identified from the samples collected at Mino-gawa, Gongen-dani, and Inado-gawa, respectively (Fig. 1).

At Mino-gawa, TuMV (genus, Potyvirus; family, Potyviridae), BrYV (genus, Polerovirus; family Luteoviridae), and Pelargonium zonate spot virus (PZSV; genus, Anulavirus; family, Bromoviridae) had more than $80 \%$ coverage and high number of reads (Fig. 1a). AhPV1 (genus, Alphapartitivirus; family, Partitiviridae) and CMV (genus, Cucumovirus; family, Bromoviridae) showed $74 \%$ and $46 \%$ coverage, respectively, and their reads were widely distributed within the viral genome. Viruses that showed 10-20\% considered mis-mappings due to partial sequence homology with BrYV (TuYV) and CMV (the other three viruses). Therefore, five virus species were considered to infect the Brassicaceae community at Mino-gawa. At Gongen-dani, PZSV and AhPV1 had more than $80 \%$ coverage and a high number of reads (Fig. 1b). No other viruses were detected with $>10 \%$ coverage. Therefore, these two species were considered to infect the Brassicaceae community at Gongen-dani. At Inado-gawa, no viral infections were detected by RNASeq (Fig. 1c). Infected plants were spatially clustered in both Mino-gawa and Gongen-dani (Fig. 2), and these clusters partly represent spatial aggregation of A. halleri and Rorippa indica distribution, within the sites (Fig. 2). 
Unmapped reads were assembled and 19,27, and 1 contig(s) were annotated to viruses of Mino-gawa,

BrYV, and PZSV or other closely related viruses, in the reference sequence, were not included in further annotated to viruses with moderate similarities and treated as candidates for putative viruses. Among these, five and two contigs correspond to RNAI and RNA2 of BdMoV, covering $33 \%$ and $27 \%$ of the two genomes, respectively (Table S3). When the seven contigs were mapped on BdMoV genome sequences, their positions did not overlap; they were widely distributed within the genome. Deduced amino acid (AA) sequences of the contigs had putative coding sequences that generated putative polypeptides similar to those produced by $R N A l$ and $R N A 2$ of $\mathrm{BdMoV}$ (70\% and $62 \%$ AA sequence similarity, respectively). To examine the co-occurrence of these contigs in each sample, the longest two contigs each from the RNAI and RNA2 of the putative novel virus (four contigs in total) were remapped using RNA-Seq data from Gongen-dani. The BdMoV-like contigs were detected in only one sample, Arabis flagellosa; therefore, the putative virus was named Arabis flagellosa Virus 1 (AflV1). The remaining 1 contig from Gongen-dani was annotated to Aspergillus foetidus slow virus 2, but the aligned sequence was short, 191 nt of a 3,634-nt reference sequence (5.3\%), and therefore this virus was not considered to be present (Table S3).

Distribution of viruses across Brassicaceae species

At Mino-gawa, viruses were detected in A. halleri and R. indica with infection rates of $80 \%$ and $8 \%$, respectively (Table 1). Five and two viruses were detected in A. halleri and $R$. indica, respectively (Table 
detected in A. halleri with an infection rate of $8 \%$, and PZSV was detected in $R$. indica with an infection rate of 37.5\%. No viral infection was detected in C. leucantha, C. impatiens, or C. hirsuta. A. flagellosa plants were not infected by the five virus species (Table 1), but putative infection by AflV1 was detected in a single plant individual. None of the seven plant species sampled at Inado-gawa (C. leucantha, $C$. impatiens, C. scutata, A. flagellosa, $R$. indica, C. hirsuta, and C. appendiculata) were infected by viruses (Table 1). Virus species composition was significantly different among the three sites and among host plant species (perMANOVA, $\mathrm{R}^{2}=0.019,0.098$, and 0.11 and $p$-value $=0.016,0.0006$, and 0.0001 for site, plant, and site-plant interaction, respectively).

Multiple infections were only observed in Mino-gawa, and therefore analyses on viral co-infections were performed on the data at the Mino-gawa site. Multiple infections by TuMV, BrYV, and CMV were significantly more frequent than that expected by chance (Fisher's test, $p<0.01$ ), especially when the plant was infected by TuMV (Fisher's test, $p<0.001$, Table S4). No significant association was observed between infections by PZSV and other viruses (Table S5).

All six strains of TuMV from Mino-gawa formed a single clade with 95\% bootstrap probability (Fig. S2). The clade was included in the world-B group, one of the four phylogenetic lineage of TuMV defined in the previous study [22], along with other strains from Omoide-gawa site (Ahg Plot) and those reported from crops (Fig. S2).

All strains of CMV obtained from A. halleri in Mino-gawa belonged to subgroup IA (sub-IA), a phylogenetic lineage of CMV (Fig. S3) [21, 28]. The sub-A group formed a clade with $87 \%$ bootstrap probability. CMV strains from Mino-gawa, like other strains in sub-IA, encoded $2 \mathrm{~b}$ proteins that were 10 

those found in cases of successful transmissions. Quadruple, triple, double, and single infections were observed in 4, 20, 21, and 11 plants, respectively. Among these plants, 3, 18, 16, and 11 transmitted whole virus sets (Table S6). Reduction in the number of transmitted species was observed; TuMV, CMV, and BrYV failed to be transmitted occasionally (Table S6).

\section{Discussion}

Infection rates differed notably among the combinations of virus, plant species and sampling sites.

Viruses turned out to infect only two perennial plant species, A. halleri and $R$. indica. Infection rates detected in the present study were similar to those reported in previous studies conducted in semi-natural plant populations. Six virus species have been reported to infect 0\%-3.8\% plants of the wild Brassica rapa populations growing close to crop fields in southern England [31]. CMV was reported to infect 18\% to $25 \%$ plants of the biennial and perennial populations of weedy Brassicaceae species in North America [32]. The most frequently detected virus in Mino-gawa and Gongen-dani was PZSV; it was reported for the first time in Japan, in these sites [33]. PZSV was known to be transmitted vertically via pollen and seeds in tomato, in addition to horizontal transmission [34]. Therefore, high infection rate of PZSV is likely to be maintained through vertical transmission in the A. halleri populations.

311 Viral infection rate was exceptionally high in A. halleri plants, and we have previously reported similar 
infected plants in its population even for non-seed-borne viruses. We expect that the high transmission rate

314 of viruses through clonal propagation of the host plant contributes primarily to the long-term maintenance of infection in the clonal linages. Then, the long-term persistence of virus in the clonal linage is likely to allow successful horizontal transmission to take place. We found that the infected plants distribute across the distance of over several hundred meters, and the pattern should require horizontal transmission. Overall, long-term persistence of viruses through clonal propagation of host plants and occasional horizontal transmission are likely to have formed the observed spatial distribution of infected plants in the host plant populations.

Phylogenetic analysis of TuMV and CMV revealed that all virus strains obtained from A. halleri in natural plant communities were closely related to the strains reported from crops. The pattern in the phylogeny suggested the presence of virus exchanges between natural plant communities and agricultural fields. Further experimental analyses are required to determine whether the strains in natural plant communities are infectious to crop plants. Previous studies also reported some evidence of the virus exchange between crops and wild plants, which implies future-emergent viruses in crops can be investigated from viruses in natural habitats $[2,42]$. plant species. This, however, was not the case in our study. Viral infection rate in $R$. indica was low although 330 it seemed to be a host of three of the five detected viruses in Mino-gawa (TuMV, BrYV, and PZSV). This suggests that viruses were horizontally transmitted to a certain degree within A. halleri, but this was not high enough for spread of viral infections to other Brassicaceae species. TuMV and BrYV were reported to be transmitted by aphids $[35,36]$, and PZSV by a thrips, which carries virus-included pollen grains on its body [34]. No viral detection from Cardamine species may represent a lack of effective means of transmission and maintenance that matches the life cycle of both host plants and vectors. It is likely that 
dependent viruses. Further studies are required on the density and distribution of vector insects in the natural plant communities.

In some cases, multiple viruses were co-existed in their shared host species, which may be the results of a certain mechanism that enhance multiple-infections. In this study, multiple infections were significantly frequent in TuMV infected leaves in Mino-gawa, which suggested that TuMV might facilitate infection of other virus species. In previous studies, promotion of replication of other viruses by potyviruses has been reported to be achieved by suppression of host RNA-silencing machinery [20, 37, 38].

From Gongen-dani, one A. flagellosa plant yielded a putative novel virus, tentatively named AfV1, which was similar to BdMoV. This member of genus Benyvirus was first reported in an edible burdock plant (Arctium lappa) in Japan and has a bisegmented RNA1 (7038 nt) and RNA2 (4315 nt) genome [39]. While RNA1 has a single ORF encoding a 249-kDa polypeptide [39], RNA2 has six ORFs encoding a coat protein, a coat-protein readthrough, three movement proteins, and a cysteine-rich protein [39]. In the present study, putative AA sequences were identified from seven contigs corresponding to a $249-\mathrm{kDa}$ polypeptide and to first and third movement proteins in the triple-gene block of BdMoV. We could not obtain the whole genome sequence of AflV1, due to the low number of AflV1 reads $\left(2.4 \times 10^{3} \mathrm{rpm}\right)$, as this is a cryptic virus [40-42] and therefore, difficult to detect.

In this study, we determined the distribution of viruses in natural Brassicaceae plant communities and analyzed the difference among plant species and localities. We also detected a novel virus candidate in this study. Further update of the virus database is clearly required, especially by accumulating sequence information of novel viruses from natural plant vegetation. Revealing ecology of viruses, host plants, and vectors will be a promising way to understand mechanisms that determine virus dynamics in natural plant communities.

\section{Conflict of Interest}


The authors declare that they have no conflict of interest.

362

363 


\section{References}

1. Tomlinson JA, Carter AL, Dale WT, Simpson CJ (1970) Weed plants as sources of cucumber mosaic virus. Annals of Applied Biology 66: 11-16. https://doi.org/10.1111/j.1744-7348.1970.tb04597.x

2. Mueller EE, Groves RL, Gratton C (2011) Crop and Non-Crop Plants as Potential Reservoir Hosts of Alfalfa mosaic virus and Cucumber mosaic virus for Spread to Commercial Snap Bean. Plant Disease 96: 506-514. https://doi.org/10.1094/PDIS-0211-0089

3. Roossinck MJ (2012) Plant virus metagenomics: biodiversity and ecology. Annu Rev Genet 46: 359-369. https://doi.org/10.1146/annurev-genet-110711-155600

4. Aranda MA, Freitas-Astúa J (2017) Ecology and diversity of plant viruses, and epidemiology of plant virus-induced diseases. Annals of Applied Biology 171: 1-4. https://doi.org/10.1111/aab.12361

5. Islam W, Zhang J, Adnan M, Noman A, Zainab M, Jian W (2017) Plant virus ecology: a glimpse of recent accomplishments. Appl Econ Environ Res 15: 691-705. http://dx.doi.org/10.15666/aeer/1501_691705

6. May RM, Anderson RM (1983) Epidemiology and genetics in the coevolution of parasites and hosts. Proc R Soc Lond B Biol Sci 219: 281-313. http://dx.doi.org/ 10.1098/rspb.1983.0075

7. Prendeville HR, Ye X, Morris TJ, Pilson D (2012) Virus infections in wild plant populations are both frequent and often unapparent. Am J Bot 99: 1033-1042. http://dx.doi.org/10.3732/ajb.1100509

8. $\quad$ Li L, Liu J, Zhang Q, Fu R, Zhu X, Li C, Chen J (2016) Seed-borne viral dsRNA elements in three cultivated Raphanus and Brassica plants suggest three cryptoviruses. Can J Microbiol 62: 287-295. http://dx.doi.org/10.1139/cjm-2015-0788

9. Alexander HM, Bruns E, Schebor H, Malmstrom CM (2017) Crop -associated virus infection in a native perennial grass: reduction in plant fitness and dynamic patterns of virus detection. J Ecol https://doi.org/10.1111/1365-2745.12723

10. Pagán I, Montes N, Milgroom MG, García-Arenal F (2014) Vertical transmission selects for reduced virulence in a plant virus and for increased resistance in the host. PLoS Pathogens 10: e1004293. http://dx.doi.org/10.1371/journal.ppat.1004293 induced by soybean mosaic virus. Plant Dis 76: 304-306. http://dx.doi.org/10.1094/PD-76-0304

12. Jones RAC, Ferris DG (2000) Suppressing spread of alfalfa mosaic virus in grazed legume pasture swards using insecticides and admixture with grass, and effects of 
400

401

402

403

404

405

406

407

408

409

410

411

412

413

414

415

416

417

418

419

420

421

422

423

424

425

426

427

428

429

430

431

432

433

434

435

insecticides on numbers of aphids and three other pasture pests. Ann Appl Biol 137: 259-271. http://dx.doi.org/10.1111/j.1744-7348.2000.tb00067.x

13. Hooks CRR, Fereres A (2006) Protecting crops from non-persistently aphidtransmitted viruses: A review on the use of barrier plants as a management tool. Virus Research 120: 1-16. http://dx.doi.org/10.1016/j.virusres.2006.02.006

14. Pedersen AB, Fenton A (2007) Emphasizing the ecology in parasite community ecology. Trends Ecol Evol 22: 133-139. http://dx.doi.org/10.1016/j.tree.2006.11.005

15. Callaway RM (1995) Positive interactions among plants. Bot Rev 61: 306-349. https://doi.org/10.1007/BF02912621

16. Seabloom EW, Borer ET, Gross K, Kendig AE, Lacroix C, Mitchell CE, Mordecai EA, Power AG (2015) The community ecology of pathogens: coinfection, coexistence and community composition. Ecol Lett 18: 401-415. https://doi.org/10.1111/ele.12418

17. Filipe J, Maule M (2004) Effects of dispersal mechanisms on spatio-temporal development of epidemics. J Theoret Biol 226: 125-141.

https://doi.org/10.1016/S0022-5193(03)00278-9

18. Gibson G (1997) Investigating mechanisms of spatiotemporal epidemic spread using stochastic models. Phytopathology 87: 139-146.

http://dx.doi.org/10.1094/PHYTO.1997.87.2.139

19. Barba M, Czosnek H, Hadidi A (2014) Historical Perspective, Development and Applications of Next-Generation Sequencing in Plant Virology. Viruses 6: 106-136. http://dx.doi.org/10.3390/v6010106

20. Kamitani M, Nagano AJ, Honjo MN, Kudoh H (2016) RNA-Seq reveals virus-virus and virus-plant interactions in nature. FEMS Microbiol Ecol 92.

http://dx.doi.org/10.1093/femsec/fiw176

21. Palukaitis P, Roossinck MJ, Dietzgen RG, Francki RI (1992) Cucumber mosaic virus. Adv Virus Res 41: 281-348.

22. Ohshima K, Yamaguchi Y, Hirota R, Hamamoto T, Tomimura K, Tan Z, Sano T, Azuhata F, Walsh JA, Fletcher J, Chen J, Gera A, Gibbs A (2002) Molecular evolution of Turnip mosaic virus: evidence of host adaptation, genetic recombination and geographical spread. J General Virol 83: 1511-1521. doi: http://dx.doi.org/10.1099/0022-1317-83-6-1511

23. Morlan JD, Qu K, Sinicropi DV (2012) Selective depletion of rRNA enables whole transcriptome profiling of archival fixed tissue. PLoS ONE 7: e42882. http://dx.doi.org/10.1371/journal.pone.0042882

24. Kamitani M, Nagano AJ, Honjo MN, Kudoh H (2016) RNA-Seq reveals virus-virus and virus-plant interactions in nature. FEMS Microbiol Ecol 92. 
436

437

438

439

440

441

442

443

444

445

446

447

448

449

450

451

452

453

454

455

456

457

458

459

460

461

462

463

464

465

466

467

468

469

470

471

http://dx.doi.org/10.1093/femsec/fiw176

25. Grabherr MG, Haas BJ, Yassour M, Levin JZ, Thompson DA, Amit I, Adiconis X, Fan L, Raychowdhury R, Zeng Q, Chen Z, Mauceli E, Hacohen N, Gnirke A, Rhind N, di Palma F, Birren BW, Nusbaum C, Lindblad-Toh K, Friedman N, Regev A (2011) Full-length transcriptome assembly from RNA-Seq data without a reference genome. Nature Biotechnol 29: 644-652. http://dx.doi.org/10.1038/nbt.1883

26. Rice P, Longden I, Bleasby A (2000) EMBOSS: the European Molecular Biology Open Software Suite. Trends Genet 16: 276-277. http://dx.doi.org/10.1016/s01689525(00)02024-2

27. Oksanen J, Blanchet FG, Kindt R, Legendre P, Minchin PR, O'Hara R, Simpson GL, Solymos P, Stevens MHH, Wagner H (2015) Vegan: Community ecology package. R package version 2.3-5. 2016.

28. Roossinck MJ, Zhang L, Hellwald KH (1999) Rearrangements in the 5' nontranslated region and phylogenetic analyses of cucumber mosaic virus RNA 3 indicate radial evolution of three subgroups. J Virol 73: 6752-6758.

29. Bashir NS, Kalhor MR, Zarghani SN (2006) Detection, differentiation and phylogenetic analysis of cucumber mosaic virus isolates from cucurbits in the northwest region of Iran. Virus Genes 32: 277-288. http://dx.doi.org/10.1007/s11262005-6912-2

30. Kumar S, Stecher G, Tamura K (2016) MEGA7: Molecular Evolutionary Genetics Analysis Version 7.0 for Bigger Datasets. Mol Biol Evol 33: 1870-1874. http://dx.doi.org/10.1093/molbev/msw054

31. Pallett D, Thurston M, Cortina - Borja M, Edwards ML, Alexander M, Mitchell E, Raybould A, Cooper J (2002) The incidence of viruses in wild Brassica rapa ssp. sylvestris in southern England. Ann Appl Biol 141: 163-170. https://doi.org/10.1111/j.1744-7348.2002.tb00209.x

32. Rist DL, Lorbeer JW (1989) Occurrence and overwintering of cucumber mosaic virus and broad bean wilt virus in weeds growing near commercial lettuce fields in New York. Phytopathology 79: 65-69. http://dx.doi.org/10.1094/Phyto-79-65

33. Kamitani M, Nagano AJ, Honjo MN, Kudoh H (2017) First report of Pelargonium zonate spot virus from wild Brassicaceae plants in Japan. J General Plant Pathol http://dx.doi.org/10.1007/s10327-017-0727-6

34. Lapidot M, Guenoune-Gelbart D, Leibman D, Holdengreber V, Davidovitz M, Machbash Z, Klieman-Shoval S, Cohen S, Gal-On A (2010) Pelargonium zonate spot virus is transmitted vertically via seed and pollen in tomato. Phytopathology 100: 798-804. http://dx.doi.org/10.1094/phyto-100-8-0798 
472

473

474

475

476

477

478

479

480

481

482

483

484

485

486

487

488

489

490

491

492

493

494

495

496

497
35. Schliephake E, Graichen K, Rabenstein FF (1999) Investigations on the vector transmission of the Beet mild yellowing virus (BMYV) and the Turnip yellows virus (TuYV)

36. Whitfield AE, Falk BW, Rotenberg D (2015) Insect vector-mediated transmission of plant viruses. Virology 479-480: 278-289. http://dx.doi.org/10.1016/j.virol.2015.03.026

37. Choi SK, Yoon JY, Ryu KH, Choi JK, Palukaitis P, Park WM (2002) Systemic movement of a movement-deficient strain of Cucumber mosaic virus in zucchini squash is facilitated by a cucurbit-infecting potyvirus. J General Virol 83: 31733178. http://dx.doi.org/10.1099/0022-1317-83-12-3173

38. Pruss G, Ge X, Shi XM, Carrington JC, Bowman Vance V (1997) Plant viral synergism: the potyviral genome encodes a broad-range pathogenicity enhancer that transactivates replication of heterologous viruses. Plant Cell 9: 859-868.

39. Kondo H, Hirano S, Chiba S, Andika IB, Hirai M, Maeda T, Tamada T (2013) Characterization of burdock mottle virus, a novel member of the genus Benyvirus, and the identification of benyvirus-related sequences in the plant and insect genomes. Virus Res 177: 75-86. http://dx.doi.org/10.1016/j.virusres.2013.07.015

40. Nibert ML, Ghabrial SA, Maiss E, Lesker T, Vainio EJ, Jiang D, Suzuki N (2014) Taxonomic reorganization of family Partitiviridae and other recent progress in partitivirus research. Virus Res 188: 128-141. https://doi.org/10.1016/j.virusres.2014.04.007

41. Boccardo G, Lisa V, Luisoni E, Milne RG (1987) Cryptic plant viruses. Adv Virus Res 32: 171-214. https://doi.org/10.1016/S0065-3527(08)60477-7

42. Roossinck MJ (2010) Lifestyles of plant viruses. Philos Trans R Soc Lond B Biol Sci 365: 1899-1905. http://dx.doi.org/10.1098/rstb.2010.0057 
500 Fig. 1 Detection of viruses from Brassicaceae communities at Mino-gawa (a), Gongen-dani, (b) and Inado-

501 gawa (c). Turnip mosaic virus (TuMV), Cucumber mosaic virus (CMV), Brassica yellows virus (BrYV),

502 Peralgonium zonate spot virus (PZSV) and Arabidopsis halleri partitivirus 1 (AhPV1) were detected from

503 Mino-gawa. PZSV and AhPV1 were detected from Gongen-dani. No virus infection was detected in Inado-

504 gawa. Maximum values of $\log _{10}$ of the read number (Y-axis) and the genome coverage (X-axis) for the

5053,981 reported virus sequence (NCBI database) are shown. Each point indicates a single virus. Gray-filled

506 points represent infecting viruses.

507

508 Fig. 2 Maps showing positions of sampled and infected plants at Mino-gawa (a), Gongen-dani, (b) and

509 Inado-gawa (c). Closed circles, open circles, and open triangles indicate positions of infected perennial,

510 non-infected perennial, and non-infected annual plants, respectively. There were no infected annuals in

511 the three localities. Alphabets represent the plant species: A, Arabidopsis halleri; F, Arabis flagellosa; D,

512 Cardamine appendiculata; H, C. hirsuta; I, C. impatiens; L, C. leucantha; O, C. occulta; S, C. scutata;

513 and R, Rorripa indica. Infected viruses were also listed by red letters. Solid and gray shaded lines

514 represented streams and sampling trails, respectively. Scale bars in each map represented $50 \mathrm{~m}$ in

515 distance. Directions are indicated by bearing marks.

516 

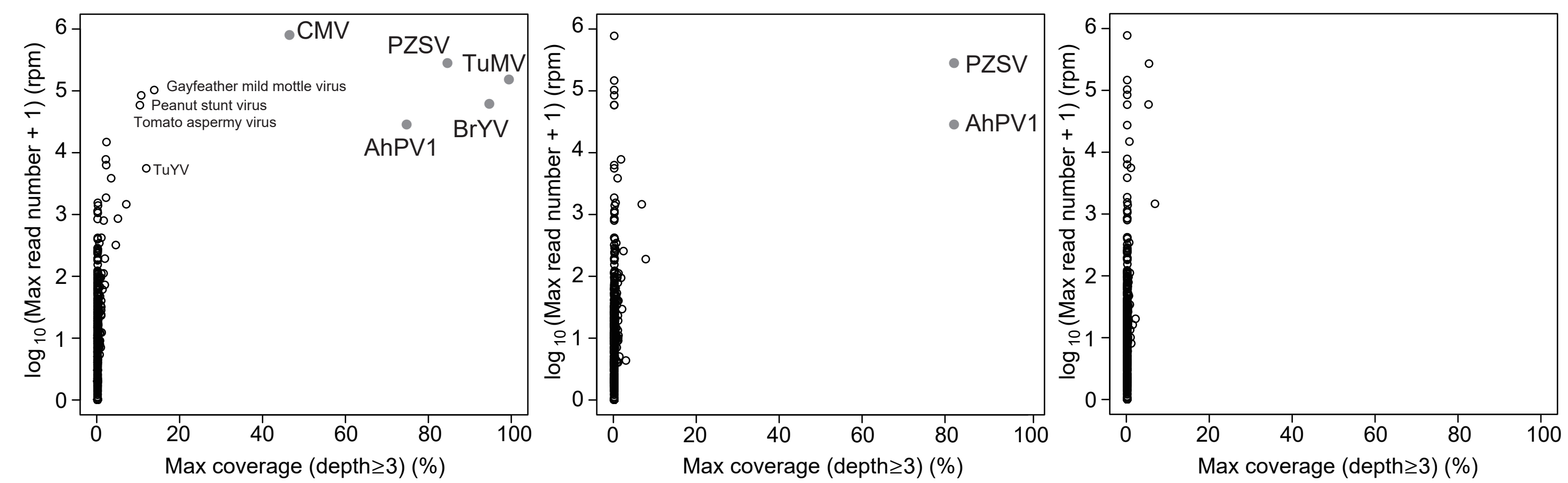

Figure 1 

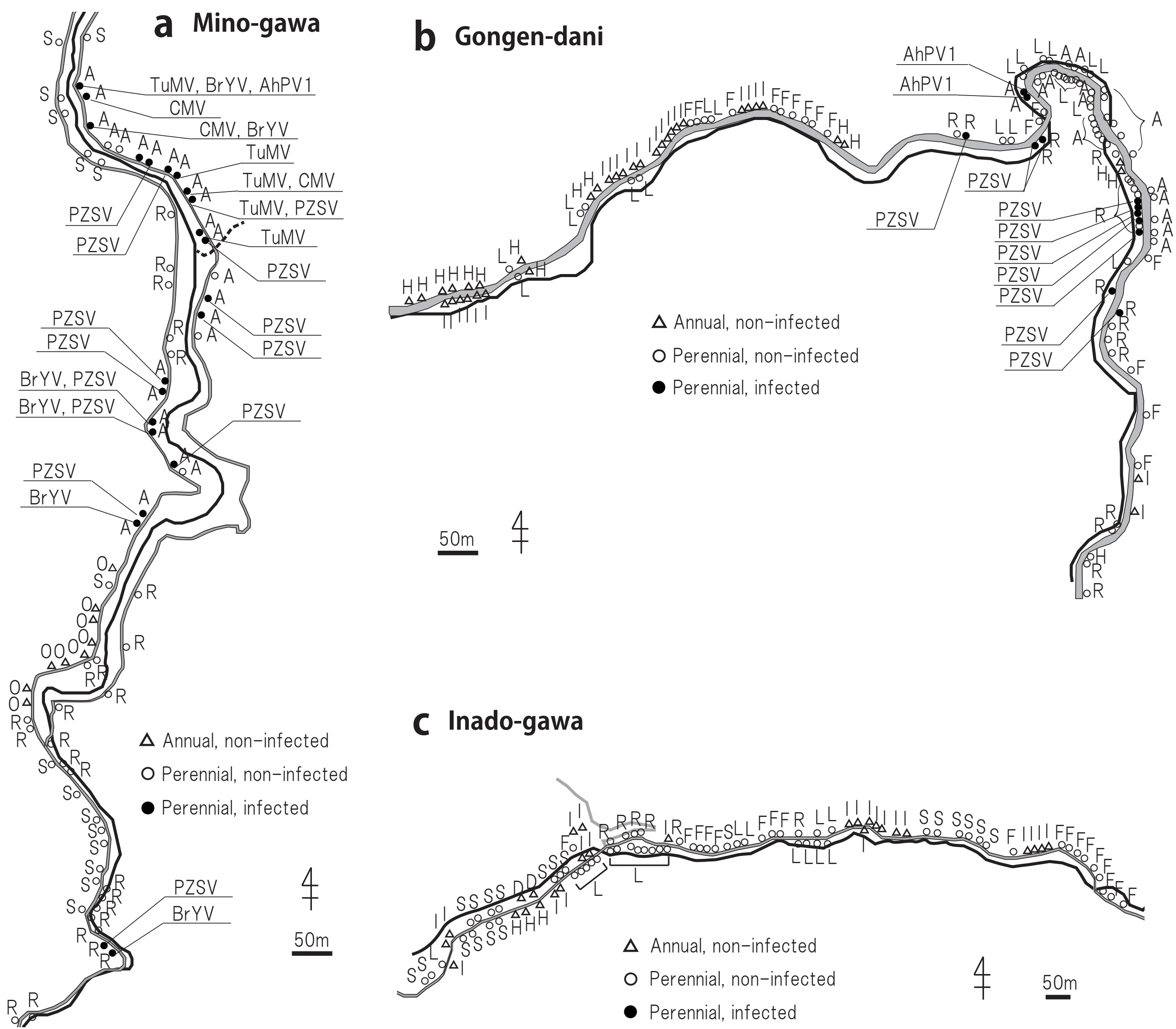

Figure 2 
Table 1 Results of virus screening of Brassicaceae communities from the three sites in this study and one site from the previous study

\begin{tabular}{|c|c|c|c|c|c|c|c|c|c|c|c|}
\hline \multirow[t]{2}{*}{$\overline{\text { Site }}$} & \multirow[t]{2}{*}{ Plant species } & \multirow{2}{*}{$\begin{array}{c}\text { Perennial/ } \\
\text { Annual }\end{array}$} & \multirow{2}{*}{$\begin{array}{c}\text { Examined } \\
\text { plants }^{(1)}\end{array}$} & \multicolumn{7}{|c|}{ Number of plants infected by viruses } & \multirow{2}{*}{$\begin{array}{c}\text { Infection } \\
\text { rate } \\
\text { (pooled) }\end{array}$} \\
\hline & & & & TuMV & CMV & BrYV & $\overline{\text { PZSV }}$ & AhPV1 & AflV1 (2) & $\begin{array}{c}\text { Pooled } \\
(3)\end{array}$ & \\
\hline Mino-gawa & $\begin{array}{l}\text { Arabidopsis halleri (L.) O'Kane et Al- } \\
\text { Shehbaz subsp. gemmifera (Matsum.) } \\
\text { O'Kane et Al-Shehbaz }\end{array}$ & Perennial & $25[12]$ & $\overline{6}$ & 4 & 5 & 13 & 1 & $\mathbf{0}$ & 20 & $80 \%$ \\
\hline Mino-gawa & Rorripa indica (L.) Hiern & Perennial & $25[12]$ & 1 & 0 & 1 & $\mathbf{1}$ & 0 & 0 & 2 & $8 \%$ \\
\hline Mino-gawa & $\begin{array}{l}\text { Cardamine scutata Thunb. subsp. regeliana } \\
\text { (Miq.) H.Hara }\end{array}$ & Perennial & $15[6]$ & 0 & 0 & 0 & 0 & 0 & 0 & 0 & $0 \%$ \\
\hline Mino-gawa & Cardamine occulta Hornem. & Annual & 8 & 0 & 0 & 0 & 0 & 0 & - & 0 & $0 \%$ \\
\hline Gongen-dani & A. halleri & Perennial & $25[12]$ & 0 & 0 & 0 & 0 & 2 & $\mathbf{0}$ & 2 & $8 \%$ \\
\hline Gongen-dani & R. indica & Perennial & $24[11]$ & 0 & 0 & 0 & 9 & 0 & $\mathbf{0}$ & 9 & $37.5 \%$ \\
\hline Gongen-dani & Cardamine leucantha (Tausch) O.E.Schulz & Perennial & $25[6]$ & 0 & 0 & 0 & 0 & 0 & 0 & 0 & $0 \%$ \\
\hline Gongen-dani & Cardamine impatiens L. & Annual & 22 & 0 & 0 & 0 & 0 & 0 & - & 0 & $0 \%$ \\
\hline Gongen-dani & Cardamine hirsuta L. & Annual & 15 & 0 & 0 & 0 & 0 & 0 & - & 0 & $0 \%$ \\
\hline Gongen-dani & Arabis flagellosa Miq. & Perennial & $15[6]$ & 0 & 0 & 0 & 0 & 0 & 1 & 0 & $16.7 \%$ \\
\hline Inado-gawa & C. leucantha & Perennial & $23[6]$ & 0 & 0 & 0 & 0 & 0 & 0 & 0 & $0 \%$ \\
\hline Inado-gawa & C. impatiens & Annual & $19[6]$ & 0 & 0 & 0 & 0 & 0 & 0 & 0 & $0 \%$ \\
\hline Inado-gawa & C. scutata & Perennial & $20[6]$ & 0 & 0 & 0 & 0 & 0 & 0 & 0 & $0 \%$ \\
\hline Inado-gawa & Arabis flagellosa & Perennial & $18[6]$ & 0 & 0 & 0 & 0 & 0 & 0 & 0 & $0 \%$ \\
\hline Inado-gawa & R. indica & Perennial & $6[6]$ & 0 & 0 & 0 & 0 & 0 & 0 & 0 & $0 \%$ \\
\hline Inado-gawa & C. hirsuta & Annual & 3 & 0 & 0 & 0 & 0 & 0 & - & 0 & $0 \%$ \\
\hline Inado-gawa & Cardamine appendiculata Franch. et Sav. & Perennial & 2 & 0 & 0 & 0 & 0 & 0 & - & 0 & $0 \%$ \\
\hline $\begin{array}{l}\text { Omoide- } \\
\text { gawa }^{(4)}\end{array}$ & A. halleri & Perennial & 68 & 39 & 18 & 21 & 0 & 56 & - & 62 & $91 \%$ \\
\hline
\end{tabular}

(1) All plants were analyzed by real-time PCR and numbers in brackets indicate the samples analyzed also by RNA-Seq

(2) The presence of a novel putative virus, AflV1, was determined only for RNA-Seq-analyzed samples

${ }^{(3)}$ Number of plants infected by any of the six detected viruses

(4) Data from Kamitani et al. 2016, and there were no other Brassicaceae species in Omoide-gawa site [25] 
Table 2 Clonal transmission of four viruses from mother to aerial daughter rosettes of $A$. halleri

\begin{tabular}{lrrrr}
\hline \hline & TuMV & CMV & BrYV & AhPV1 \\
\hline Examined pairs of mother and daughter rosettes & 56 & 56 & 56 & 56 \\
Infected mother rosettes & 50 & 37 & 6 & 36 \\
\hline Infected daughter rosettes & 46 & 34 & 5 & 36 \\
Uninfected pairs & 6 & 19 & 50 & 20 \\
Infection rate of mother rosettes & $89 \%$ & $66 \%$ & $11 \%$ & $64 \%$ \\
Transmission rate from mother to daughter rosettes & $92 \%$ & $92 \%$ & $83 \%$ & $100 \%$ \\
\hline
\end{tabular}



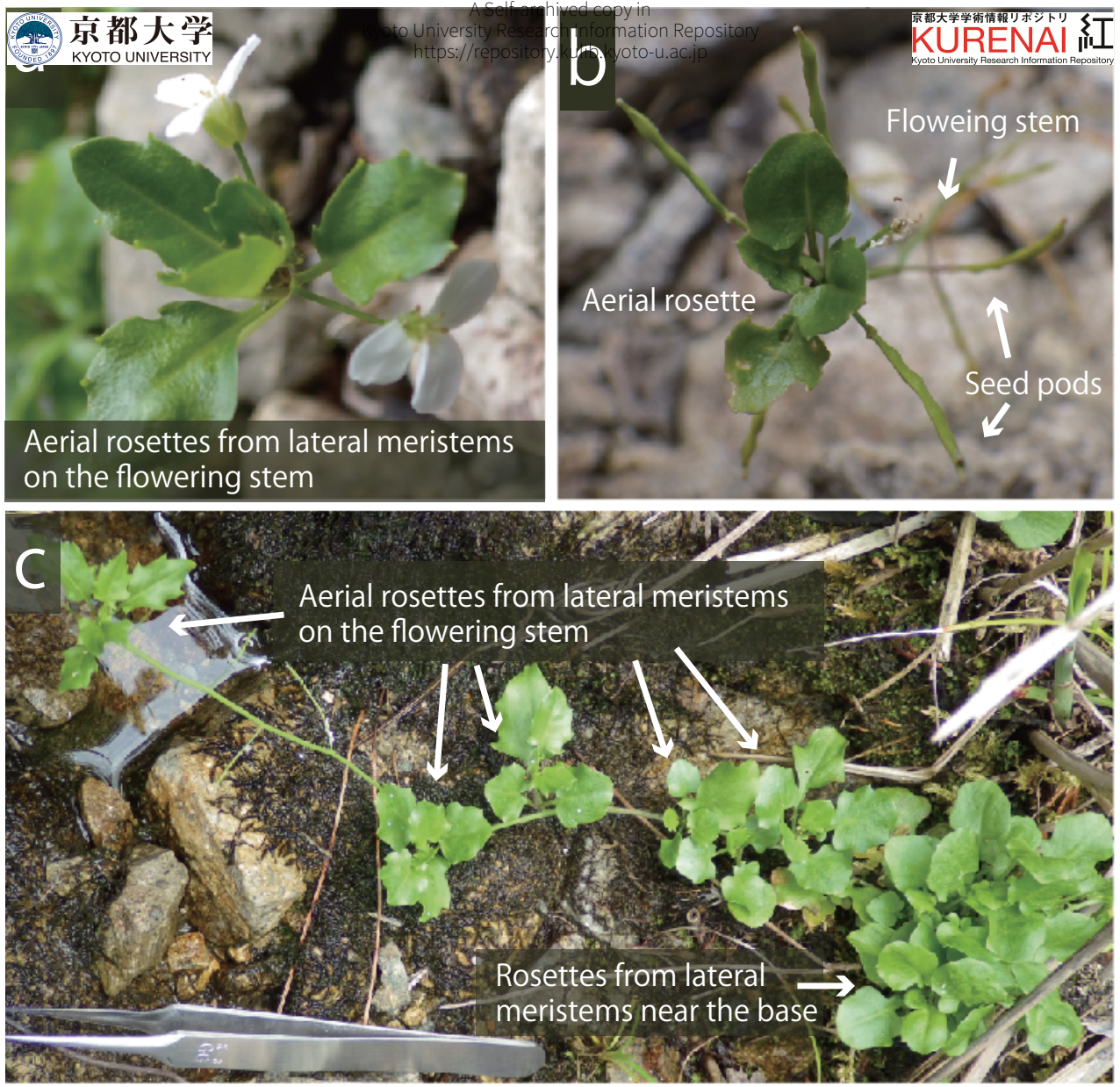

Fig. S1 Clonal propagation of Arabidopsis halleri. An aerial daughter rosette formed at the shootapical meristem (i.e. top of inflorescence) during flowering (a) and after flowering (b). Clonal daughter rosettes from shoot apical meristems and lateral meristems on a flowering stem, and basal lateral meristems (c)

Kamitani M*, Nagano AJ, Honjo M, Kudoh H* "A Survey on Plant Viruses in Natural Brassicaceae Communities Using RNA-Seq" Microbial Ecology. Hiroshi Kudoh: kudoh@ecology.kyoto-u.ac.jp 


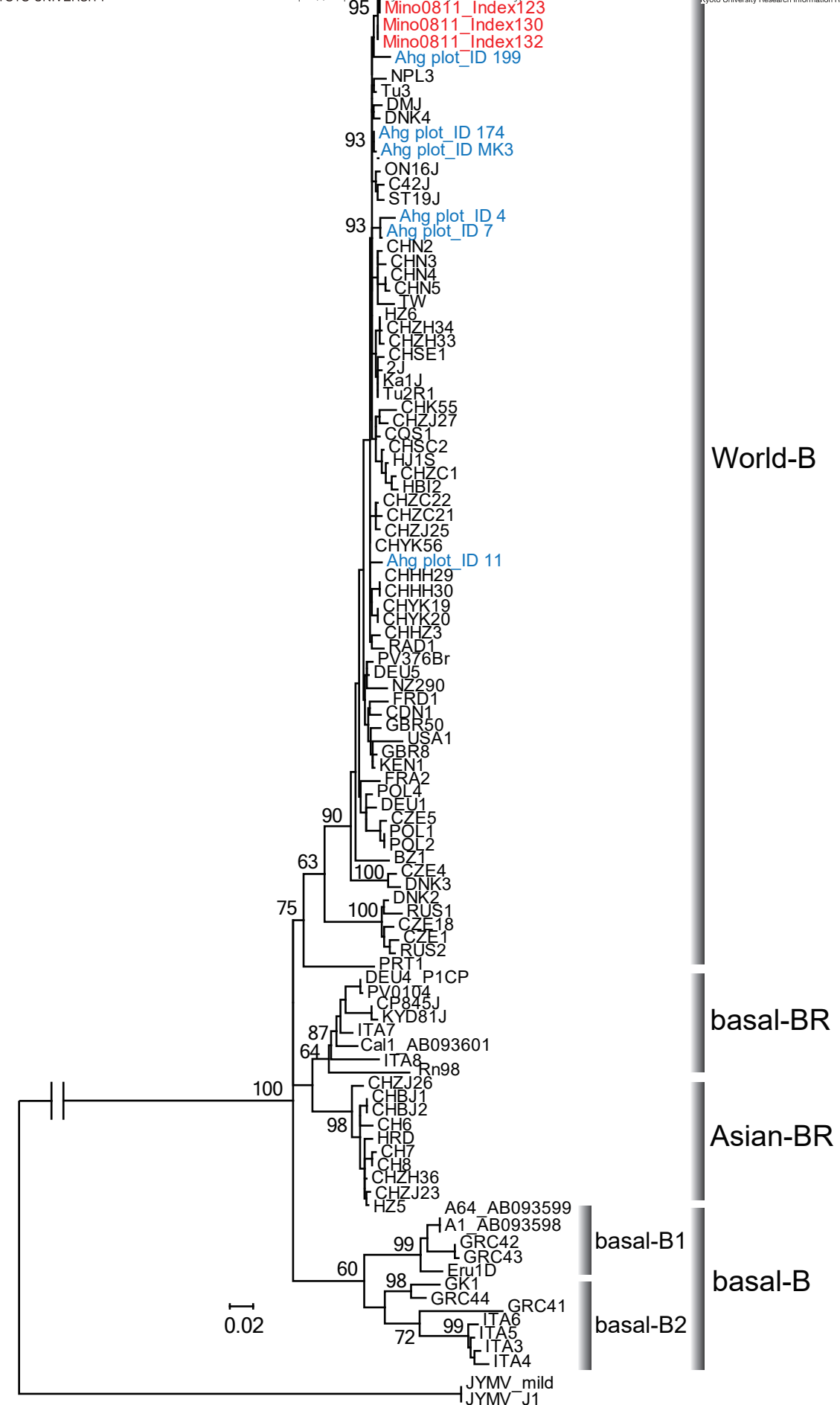

Fig. S2 Phylogenetic analysis on six strains of TuMV from A. halleri in Mino-gawa (red) based on P1 and CP sequences. Strains obtained from another natural A. halleri population (Omoide-gawa, Hyogo Pref., Japan) in our previous study are shown in blue characters (Kamitani et al. 2016). Sequences of other reported virus strains were obtained from Ohshima et al. (2002). Mild strain and J1 strain of Japanese yam mosaic virus (JYMV) were used as out-groups (Fuji and Nakamae, 2000, Fuji and Nakamae, 1999). Numbers represent bootstrap values (percentages) and values more than $60 \%$ are listed. 


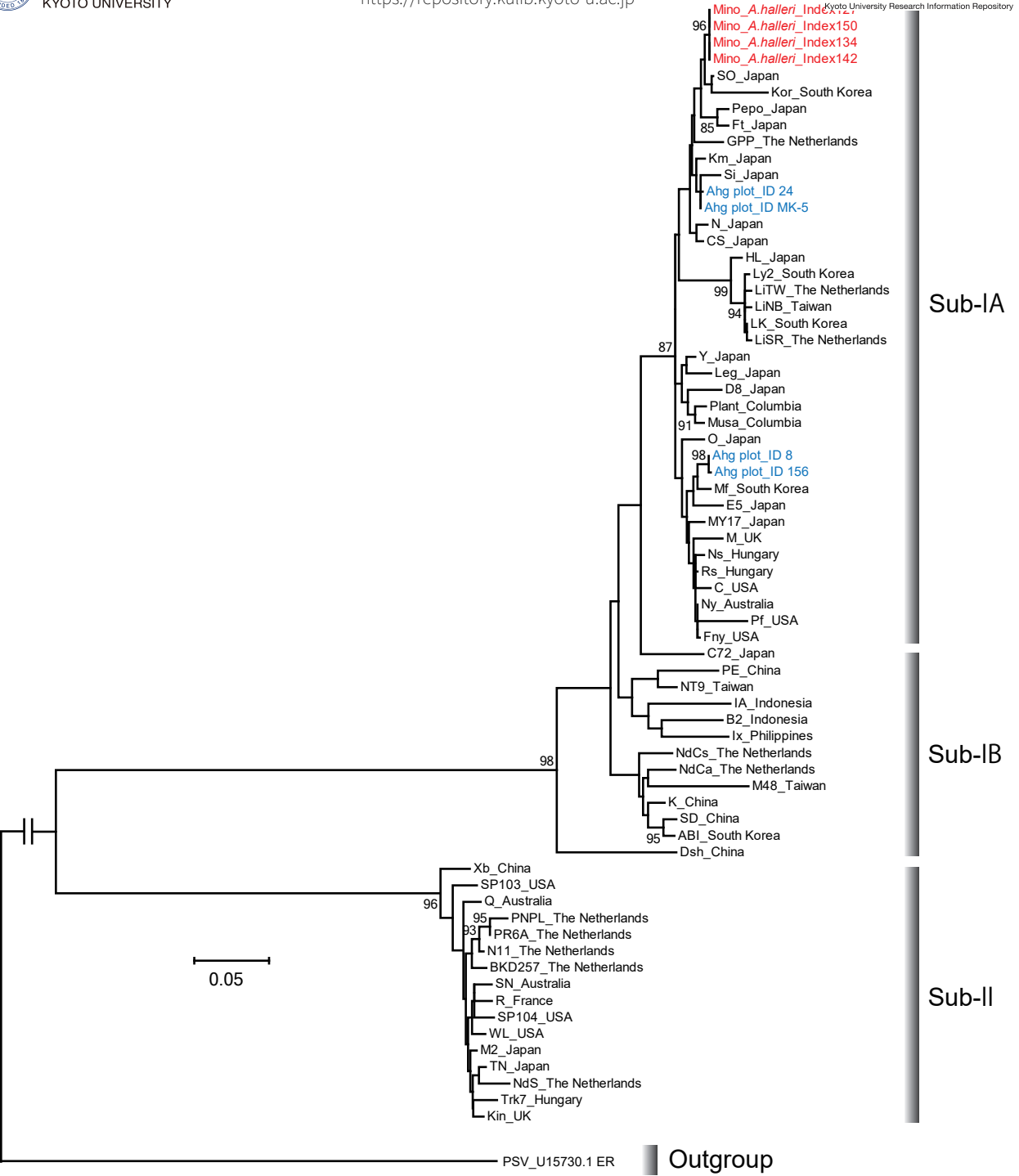

Fig. S3 Phylogenetic locations of four strains of CMV from A. halleri of Mino-gawa (red) based on sequences of CP open reading frame (ORF) plus 92 and $123 \mathrm{bp}$ of the $5^{\prime}$ and $3^{\prime}$ untranslated region, respectively. Strains with blue color indicate CMV detected from the Omoide-gawa A. halleri population (Kamitani et al. 2016). Previously reported CMV strains were included (Bashir et al. 2006). Peanut stunt virus (PSV, GenBank Accession No. U15730.1) was used as an out-group. Numbers represent bootstrap values (percentages) and values more than $80 \%$ are listed. 
Kamitani $\mathrm{M}^{*}$, Nagano AJ, Honjo M, Kudoh $\mathrm{H}^{*}$ "A Survey on Plant Viruses in Natural Brassicaceae Communities Using RNA-Seq" Microbial Ecology.

*Corresponding author Hiroshi Kudoh: kudoh@ecology.kyoto-u.ac.jp

Table S1 Primers used for virus detection and internal control in RT-qPCR

\begin{tabular}{|c|c|c|}
\hline & forward $\left(5^{\prime}-3^{\prime}\right)$ & reverse $\left(5^{\prime}-3^{\prime}\right)$ \\
\hline Turnip mosaic virus (TuMV) ${ }^{(1)}$ & TGGCTGATTACGAACTGACG & CTGCCTAAATGTGGGTTTGG \\
\hline Cucumber mosaic virus (CMV) & CAACTGGCTCGTATGGTGGA & CCTTCTCGCTGGGACTTTTG \\
\hline \multirow[t]{2}{*}{ Brassica yellows virus (BrYV) } & TGAAAGCAGACAACTCATGG & GACCGACCAGAAAGAACGA \\
\hline & AAG & TG \\
\hline Pelargonium zonate spot virus & AGATTTTTCCGGGCTCTCTA & GTTCAACTGTTTTACCAGGA \\
\hline (PZSV) & & TAG \\
\hline Arabidopsis halleri partitivirus 1 & ATGAAGAACACCGTCGTTCT & GACTTCAGTTTCCCGTCATA \\
\hline (AhPV1) & $\mathrm{C}$ & $\mathrm{C}$ \\
\hline \multirow[t]{2}{*}{ ACT2 (host gene, positive control) ${ }^{(2)}$} & TCCCTCAGCACATTCCAGCA & AACGATTCCTGGACCTGCCT \\
\hline & GAT & CATC \\
\hline
\end{tabular}

(1) Wei T, Zhang C, Hou X, Sanfaçon H, Wang A (2013) The SNARE Protein Syp71 Is Essential for Turnip

Mosaic Virus Infection by Mediating Fusion of Virus-Induced Vesicles with Chloroplasts. PLOS Pathogens 9(5): e1003378. https://doi.org/10.1371/journal.ppat.1003378

(2) Skirycz A, Jozefczuk S, Stobiecki M, Muth D, Zanor MI, Witt I, Mueller - Roeber B (2007) New Phytol. 175:425-438, https://doi.org/10.1111/j.1469-8137.2007.02129.x 
Kamitani $\mathrm{M}^{*}$, Nagano AJ, Honjo M, Kudoh H* "A Survey on Plant Viruses in Natural Brassicaceae Communities Using RNA-Seq” Microbial Ecology.

*Corresponding author Hiroshi Kudoh: kudoh@ecology.kyoto-u.ac.jp

Table S2 Break down of the contigs obtained by de novo assembly

\begin{tabular}{|c|c|c|c|c|}
\hline & & Mino-gawa & Gongen-dani & Inado-gawa \\
\hline \multicolumn{2}{|c|}{ Number of unmapped-read } & $28,489,176$ & $81,378,310$ & $14,339,016$ \\
\hline \multicolumn{2}{|c|}{ Number of contigs (Total) } & 827 & 3,831 & 415 \\
\hline \multicolumn{2}{|c|}{$\begin{array}{l}\text { Viruses (high similarity with } \\
\text { reported ones) }\end{array}$} & 19 & 19 & 1 \\
\hline \multicolumn{2}{|c|}{$\begin{array}{l}\text { Viruses (moderate similarity with } \\
\text { reported ones) }\end{array}$} & 0 & $8^{(3)}$ & 0 \\
\hline Number of & Plants & 580 & 1457 & 346 \\
\hline contigs & Animals & 2 & 1758 & 1 \\
\hline $\begin{array}{l}\text { annotated to } \\
\text { other }\end{array}$ & Fungi & 20 & 182 & 11 \\
\hline organisms & Bacteria & 10 & 17 & 9 \\
\hline \multicolumn{2}{|l|}{ Not annotated } & 165 & 314 & 36 \\
\hline
\end{tabular}

(1) Number of contigs annotated to viruses in reference list and considered to be derived from TuMV, CMV, BrYV, and PZSV

(2) Number of contigs annotated to other viruses with moderate similarities and treated as candidates for putative novel viruses

(3) Seven contigs $(971,404,372,353$, and $210 \mathrm{nt})$ were annotated to Burdock mottle virus and regarded as a putative novel virus, Arabis flagellosa Virus 1 (AflV1). The remained one contig was annotated to Aspergillus foetidus slow virus 2, but the sequence length was too short to represent the presence of the virus 
Kamitani M*, Nagano AJ, Honjo M, Kudoh H* "A Survey on Plant Viruses in Natural Brassicaceae Communities Using RNA-Seq" Microbial Ecology.

*Corresponding author Hiroshi Kudoh: kudoh@ecology.kyoto-u.ac.jp

Table S3. The length and annotation of the eight candidate contigs of novel virus

\begin{tabular}{|c|c|c|c|c|}
\hline No. & $\begin{array}{l}\text { Length of } \\
\text { the contigs }\end{array}$ & Annotation & Identity $^{(1)}$ & Coverage $^{(2}$ \\
\hline 1 & 971 & Burdock mottle virus (BdMoV) RNA2 & $70 \%$ & \multirow{5}{*}{$33 \%$} \\
\hline 2 & 404 & BdMoV RNA2 & $77 \%$ & \\
\hline 3 & 372 & BdMoV RNA2 & $71 \%$ & \\
\hline 4 & 353 & BdMoV RNA2 & $67 \%$ & \\
\hline 5 & 210 & BdMoV RNA2 & $80 \%$ & \\
\hline 6 & 929 & BdMoV RNA1 & $67 \%$ & \multirow{2}{*}{$27 \%$} \\
\hline 7 & 237 & BdMoV RNA1 & $73 \%$ & \\
\hline 8 & 191 & Aspergillus foetidus slow virus 2 & $68 \%$ & $5.3 \%$ \\
\hline
\end{tabular}

${ }^{(1)}$ Sequence identity of contigs with the annotated reference sequence

(2) The percentage of length of reference viral genome covered by the contigs 
Kamitani M*, Nagano AJ, Honjo M, Kudoh H* "A Survey on Plant Viruses in Natural Brassicaceae Communities Using RNA-Seq" Microbial Ecology.

*Corresponding author Hiroshi Kudoh: kudoh@ecology.kyoto-u.ac.jp

Table S4 Contingency tables for infections by pairs of viruses (TuMV, CMV, and BrYV) at Mino-gawa.

Significance levels in Fisher's exact test are also listed

\begin{tabular}{lcccc}
\hline \multicolumn{2}{l}{ Contingency table } & & & Significance \\
\cline { 1 - 3 } Infection & TuMV+ & TuMV- & & $*$ \\
CMV+ & 2 & 2 & & $*$ \\
CMV- & 5 & 64 & & \multirow{2}{*}{$* *$} \\
\cline { 1 - 2 } BrYV+ & TuMV+ & TuMV- & & \\
BrYV- & 5 & 3 & \\
\cline { 1 - 2 } BrYV+ & 11 & 181 & & $*$ \\
BrYV- & 2 & 4 & \\
\hline
\end{tabular}

$* p<0.05$

$* * p<0.01$

Table S5 Contingency tables for infections by PZSV and other three virus species at Mino-gawa. Significance levels in Fisher's exact test are also listed

\begin{tabular}{|c|c|c|c|}
\hline \multicolumn{3}{|c|}{ Contingency table } & \multirow[t]{2}{*}{ Significance } \\
\hline & $\overline{\text { PZSV+ }}$ & $\overline{P Z S V-}$ & \\
\hline TuMV+ & 1 & 6 & n.s. \\
\hline TuMV- & 13 & 53 & \\
\hline & PZSV+ & PZSV- & \\
\hline CMV+ & 0 & 4 & n.s. \\
\hline CMV- & 14 & 55 & \\
\hline & PZSV+ & PZSV- & \\
\hline BrYV+ & 2 & 4 & n.s. \\
\hline BrYV- & 2 & 65 & \\
\hline
\end{tabular}

n.s., no significance at $p<0.05$ 
Kamitani M*, Nagano AJ, Honjo M, Kudoh H* "A Survey on Plant Viruses in Natural Brassicaceae Communities Using RNA-Seq” Microbial Ecology.

*Corresponding author Hiroshi Kudoh: kudoh@ecology.kyoto-u.ac.jp

Table S6 Combinations of clonal transmission of viruses observed from mother to daughter rosettes of Arabidopsis halleri

\begin{tabular}{llr}
\hline \hline Viruses detected in mother rosettes & Viruses detected in daughter & Number of cases \\
\hline rosettes & \\
\hline TuMV, CMV, BrYV, AhPV1 & TuMV, CMV, BrYV, AhPV1 & 3 \\
TuMV, CMV, AhPV1 & TuMV, CMV, AhPV1 & 1 \\
TuMV, CMV, AhPV1 & TuMV, CMV, AhPV1 & 16 \\
TuMV, CMV, AhPV1 & TuMV, AhPV1 & 1 \\
TuMV, CMV, BrYV & CMV, AhPV1 & 1 \\
TuMV, BrYV, AhPV1 & TuMV, CMV, BrYV & 1 \\
TuMV, CMV & TuMV, BrYV, AhPV1 & 1 \\
TuMV, CMV & TuMV, CMV & 8 \\
TuMV, CMV & TuMV & 2 \\
TuMV, AhPV1 & CMV & 1 \\
TuMV, AhPV1 & TuMV, AhPV1 & 2 \\
CMV, AhPV1 & AhPV1 & 7 \\
TuMV & CMV, AhPV1 & 2 \\
CMV & TuMV & 1 \\
AhPV1 & CMV & 2 \\
\hline \hline
\end{tabular}

